\title{
Social Networks \\ And Entrepreneurial Growth
}

Sherry Robinson, Pennsylvania State University, USA/Buskerud University College, Norway

Hans Anton Stubberud, Buskerud University College, Norway

\begin{abstract}
Social networks are important to new entrepreneurs and small business owners because the ability to access information, advice, and necessary resources is vital to the success of new firms. This study examines the social networks of European business owners according to employment size after approximately three years of survival as a business. The results show that the sources of advice used at start-up varied by the size of business with employers of ten or more people more likely to report having received advice from professional acquaintances, financial institutions and training programs, and less likely to have received advice from family and friends or professional consultants. Although these people were more likely to report that they did not need advice, they were also the least likely to report that they had no access to advice. Those with between one and nine employees were the most likely to report using professional consultants (a formal source), suggesting their informal social networks were not as well-developed.
\end{abstract}

Keywords: Social Networks; Advice; Small Business Owners; Entrepreneurs

\section{INTRODUCTION}

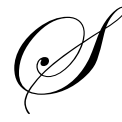

ocial networks are becoming increasingly important to business owners as they provide firms with access to markets, ideas, information, advice, business opportunities, and other resources (Birley, 1985; Fang, Tsai, \& Lin, 2010; Farr-Wharton \& Brunetto, 2007; Gulati, Nohria \& Zaheer, 2000; Hoang \& Antoncic, 2003; Lee \& Jones, 2008; Shaw, 2006; Taylor \& Thorpe, 2004). Entrepreneurs are, to some extent, dependent on their networks of personal relationships, especially informal networks, when making decisions and solving problems (Shaw, 1006; Taylor \& Thorpe, 2004). One result of networking is the development of social capital, which essentially consists of the "resources individuals obtain from knowing others, being part of a network with them, or merely being known to them and having a good reputation" (Nahapiet \& Ghoshal, 1998, p. 107). The end result is that networks are related to the survival and growth of new firms (Bruderl \& Preisendorfer, 1998). According to Anderson, Park and Jack (2007, p. 265), "it could even be argued that it is through social relations, social interaction and social networks that entrepreneurship is actually carried out." The following section provides a brief review of the nature and importance of social networks to businesses. The methodology of this study, as well as the results and analysis are then provided.

\section{SOCIAL NETWORKS}

Social networks are the key to unlocking and gaining access to other resources as they facilitate communication between people with network ties (Anderson et al., 2007). Granovetter (1973) classified network ties as either weak or strong based on the frequency of contact, which was itself associated with reciprocity. Relationships with friends and family were categorized as strong ties because of frequent contact and emotional closeness. In contrast, ties between business associates, consultants, and other such contacts were classified as weak ties because of less frequent contact. Granovetter also argued that "the strength of weak ties" was related to diversity in sources of knowledge and advice in that "individuals with few weak ties will be deprived of information from distant parts of the social system and will be confined to the provincial news and views of their close friends" (1973, p. 106). However, frequency of contact is not necessarily sufficient as the sole measure of network quality because the exchange of useful information is not guaranteed--there is only the opportunity for exchange (Frenzen \& 
Nakamoto, 1993, p. 369; Zhao \& Aram, 1995). For example, a strong tie with a friend or family member with whom one interacts frequently is not necessarily useful in a business setting, whereas a weak tie with a business consultant would be expected to yield more useful information.

Nebus (2006) contends that the most favorable situation is one in which social contacts also happen to be experts because social contacts are easier to access and more likely to willingly communicate. In contrast, experts are more likely to have valuable information, but are more difficult to access. Informal socializing can be important to building social capital and eventually business growth (Bowey \& Easton, 2007). A business owner might need to an "exploration" strategy in order to discover and contact experts with whom he or she does not already have a relationship, whereas relying on already established contacts could be considered an "exploitation" strategy (March, 1991). Naturally, the exploitation strategy is likely to be less costly in terms of time, effort and other resources. There is a trade-off to be made between the quality of information and the cost (including time) of obtaining it (Casson \& Giusta, 2007; Haas \& Hansen, 2005; Hansen \& Haas, 2002).

Networks that include people who are not well-acquainted with each other usually provide a wider variety of resources, viewpoints, ideas, and information than less diverse networks composed mostly of family and friends who know each other (Smeltzer, Van Hook \& Hutt, 1991). Founders with varied networks of contacts, especially contacts with people who are themselves well connected (for example, incubator managers), are in a better position to gain information to help them surmount business development problems, thus shaping their own survival and growth (Aldrich, 1989; Burt, 1982; Fang et al., 2010; Lee \& Jones, 2008; Low \& MacMillan, 1988; Robinson \& Stubberud, 2009a; Zhao \& Aram, 1995).

Using data from a survey conducted by the Australian government of employers with fewer than 200 workers, Watson (2007) found that banks and accountants were the primary source of advice. However, Smeltzer, Fann and Nikolesean (1988) found that small business managers more often used informal than formal sources. However, Bruderl and Preisendorfer (1998) found that support from strong ties was more important to start-ups' success than weak ties. Similarly, smaller ventures have been found to use friends and family more, but banks less, than larger ventures do (Cooper et al., 1989; Robinson \& Stubberud, 2009b). Birley (1985) found that the type of source accessed was related to the resources desired. When assembling raw materials/supplies, equipment, location/premises, and employees, business contacts were used most. Family and friends were also important for assembling local resources (location/premises and employees). Once these resources were obtained, business owners sought resources from banks. However, Birley's study examined resource access, rather than access to sources of advice, in which case banks would rationally be the primary sources.

It is clear from the literature that a business owner's network can influence the performance of his or her business (Birley, 1985; Bruderl \& Preisendorfer, 1998; Farr-Wharton \& Brunetto, 2007; Gulati, Nohria \& Zaheer, 2000; Hoang \& Antoncic, 2003; Taylor \& Thorpe, 2004). The quality of information obtained from different sources is likely to vary based on the expertise of the given knowledge source, and that may eventually have an effect on the growth of a business. To further examine this issue, this study examines the sources of advice used by successful business owners in Europe.

\section{METHODOLOGY, RESULTS AND ANALYSIS}

The data for this study were gathered from Eurostat's metadata database (Eurostat, 2010). The target population of this 2005-2006 survey consisted of people who had started businesses in 2002 and were still personally managing them in 2005. The countries included in the "European aggregate based on available data," were the Czech Republic, Denmark, Italy, Lithuania, Luxembourg, Austria, Slovakia, Sweden, and Bulgaria. Romania was originally included in this data set, but is not included in this study because of incomplete data. A total of 287,837 people are included in this study.

Business owners were asked to indicate if they had used each of the sources of advice listed in the survey. Following Birley (1985), Cooper, Woo, and Dunkelberg (1989), Littunen (2000), and Watson (2007), these sources were categorized as informal sources (family and friends; professional acquaintances), formal sources (professional consultants; training course for entrepreneurs; organizations specializing in business start-ups; unemployment 
administrations; financial institutions), and no sources (no access to relevant sources; no need for advice). The percentage of people who reported using each of these sources of advice was analyzed in light of the size of the business at the time of the survey.

As shown in Table 1, the informal sources "professional acquaintances" and "family and friends" were the top sources of advice for the owners of businesses of all sizes. However, entrepreneurs with ten or more employees were clearly more likely to have relied on professional acquaintances for advice at the time of start-up. At the same time, they were the least likely to have received advice from family and friends or the formal source "professional consultants." This may be because they had enough (informal) professional acquaintances that it was not necessary to pay for advice. Those who were employers of smaller businesses were the most likely to have used consultants, suggesting that they needed more advice than non-employer firms, but did not have access to professional acquaintances with the needed information, possibly because they had less-developed social networks.

Table 1

Sources of Advice by Size of Business

\begin{tabular}{llllll}
\hline Source & 0 employees & $\mathbf{1 - 9}$ employees & $\mathbf{1 0}$ or more & Chi-sq & p< \\
\hline Professional acquaintances & $41.9 \%$ & $44.8 \%$ & $48.5 \%$ & 311 & .001 \\
Family and friends & 41.5 & 43.5 & 39.8 & 103 & .001 \\
Professional consultants & 20.5 & 25.5 & 17.6 & 844 & .001 \\
No need for advice & 20.3 & 17.7 & 21.3 & 224 & .001 \\
No access to advice & 14.8 & 12.3 & 10.9 & 353 & .001 \\
Organizations that specialize & & & & & .001 \\
$\quad$ in helping small business & 8.4 & 7.9 & 3.2 & 370 & .001 \\
Training programs & 5.3 & 5.2 & 6.5 & 29 & .001 \\
Unemployment office & 3.7 & 2.4 & 2.2 & 304 & .001 \\
Financial institutions & 1.3 & 2.3 & 3.3 & 466 & \\
\hline
\end{tabular}

The proposition that business owners with ten or more employees were well connected is also supported by the finding that they were the least likely to report that they had "no access to advice." However, given that they were also the most likely to report that they had "no need for advice," these may have been people who came from industry with the necessary knowledge or were serial entrepreneurs. Unfortunately, one limitation of this study is that the data do not allow for deeper analysis of these relationships and participants' backgrounds.

Another connection that larger employers seem to have is a relationship with financial institutions. Although only $3.3 \%$ of those with ten or more employees received advice from this source, they were more than twice as likely to use that source as were those with no employees. They were also more likely to have received formal training, but not from an organization that specializes in helping small businesses, as those organizations seemed to be more popular among small employers and non-employers. Overall, those with few or no employees tended to be fairly similar in terms of sources used, while larger employers were different, with more of them relying on professional acquaintance and fewer of them receiving advice from family and friends.

\section{CONCLUSION}

All three groups of participants were more likely to use informal sources of advice (professional acquaintances and family and friends) than formal sources. The results show that entrepreneurs who had grown their businesses so that they employed ten or more people were more likely to have used professional acquaintances as a source of advice than were those with fewer employees. Those with no employees were the least likely to have accessed this source of advice. Although family and friends were the second most commonly used source of advice for all three groups, those with ten or more employees were the least likely to have used this source. Those with between one and nine employees were the most likely to have used family and friends. This suggests that people who wanted to start growing businesses needed advice (more than non-employers), but were not well-connected with professional acquaintances from who they could receive advice. This may, in turn, be connected to this group's high usage of professional consultants. Those with no employees were the most likely to have said that they had no access to advice, but those with ten or more employees were the most likely to say they had no need for advice. 
Taken together, these results suggest that advice is indeed an important resource for starting and growing a business. Although personal goals also can influence business growth, access to important information can also have an effect. It would appear from these results that those with ten or more employees at the time of the survey had strong enough social networks that they were able to obtain needed advice on an informal basis, whereas those who had grown their businesses to a lesser extent had weaker networks such that they had to rely on family and friends or pay consultants. Further research should examine the role of social networks and the extent to which potential entrepreneurs have access to advice networks. Many entrepreneurs who wish to grow larger businesses may be restricted by their lack of strong social networks. This is, however, a problem that can be addressed by groups and agencies that seek to help new business founders and encourage entrepreneurship.

\section{REFERENCES}

1. Aldrich, H. (1989). Networking among women entrepreneurs. In O. Hagan, C. Rivchun, \& D. Sexton (Eds), Women-owned businesses, 103-132, New York: Praeger.

2. $\quad$ Aldrich, H., P.R. Reese, \& P. Dubini. (1989). Women on the verge of a breakthrough: Networking among entrepreneurs in the United States and Italy. Entrepreneurship and Regional Development, 1, 339-356.

3. Anderson, A. \& J. Park. (2007). Entrepreneurial social capital - Conceptualizing social capital in new hightech firms. International Small Business Journal, 25(3), 245-272.

4. $\quad$ Bergek, A. \& C. Norrman. (2008). Incubator best practice: A framework. Technovation, 28 20-28.

5. Birley, S. (1985). The role of networks in the entrepreneurial process. Journal of Business Venturing, 3(1), 107-117.

6. Bowey, J. L. \& G. Easton. (2007). Entrepreneurial social capital unplugged - An activity-based analysis. International Small Business Journal, 25(3), 273-306.

7. Brass, D. J. (1985). Men's and women's networks: A study of interaction patterns and influence in an organization. Academy of Management Journal, 28(2), 327-343.

8. $\quad$ Bruderl, J. \& P. Preisendorfer. (1998). Network support and the success of newly founded businesses. Small Business Economics, 19, 213-225.

9. Brush, C. (1997). Women's entrepreneurship. Proceedings of the OECD Conference on Women Entrepreneurs in Small and Medium Enterprises, OECD, Paris.

10. Burke, R. J., M. G. Rothstein, \& J. M. Bristor. (1995). Interpersonal networks of managerial and professional women and men: Descriptive characteristics. Women in Management Review, 10(1), 21-27.

11. Burt, R. S. (1982). Toward a structure theory of action. New York: Academic Press.

12. Casson, M. \& M.D. Giusta. (2007). Entrepreneurship and social capital - Analyzing the impact of social networks on entrepreneurial activity from a rational action perspective. International Small Business Journal, 25(3), 220-244.

13. Cohen, W.M., \& D. A. Levinthal. (1990). Absorptive capacity: A new perspective on learning and innovation. Administrative Science Quarterly, 35, 128-152.

14. Cooper, A. C., C. Woo, C., Y. Dunkelberg, \& C. William. (1989). Entrepreneurship and the initial size of firms. Journal of Business Venturing, 4(5), 317-334.

15. DeWine, S. \& D. Casbolt. (1983). Networking: External communication systems for female organizational members. Journal of Business Communication, 20(2), 57-67.

16. Eurostat. (2010). Epp.eurostat.ec.europa.eu. retrieved 4.February 2009.

17. Fang, S., F. Tsai, \& J. L Lin. (2010). Leveraging tenant-incubator social capital for organizational learning and performance in incubation programme. International small Business Journal, 28(1), 90-113.

18. Farr-Wharton, R. \& Y. Brunetto. (2007). Women entrepreneurs, opportunity recognition and governmentsponsored business networks: A social capital perspective. Women in Management Review, 22(3), 187-207.

19. Fielden, S. L., M. J. Davidson, A. J. Dawe, \& P. J. Makin. (2003). Factors inhibiting the economic growth of female owned small businesses in North West England. Journal of Small Business and Enterprise Development, 10(2), 152-166.

20. Frenzen, J. \& K. Nakamoto. (1993). Structure, cooperation, and the flow of market information. Journal of Consumer Research, 20 (December), 360-75.

21. Galunic, C., \& P. Moran. (1999). Social capital and productive exchange: Structural and relational embeddedness and managerial performance link. Manuscript, London Business School.

22. Granovetter, M. 1973. The strength of weak ties. American Journal of Sociology, 78:1360-1380 
23. Gray, C. (2006). Absorptive capacity, knowledge management and innovation in entrepreneurial small firms. International Journal of Entrepreneurial Behavior and Research, 12(6), 345-360.

24. Gulati R., N. Nohria, \& A. Zaheer. (2000). Strategic networks. Strategic Management Journal, 21(3), 203215.

25. Haas, M. R. \& Hansen, M. T. (2005). When using knowledge can hurt performance: The value of organizational capabilities in a management consulting company. Strategic Management Journal, 26,1 , 24.

26. Hansen, M. T. \& Haas, M. (2002). Are organizational capabilities valuable? An empirical test of the pitfalls of leveraging knowledge. Paper presented at the annual meeting of the Academy of Management, Denver.

27. Hardy, A. P. (1982). The selection of channels when seeking information: Cost/benefit vs least-effort. Information Processing \& Management, 18(6), 289-293.

28. Hisrich, R. \& C. Brush. (1986). The woman entrepreneur. Lexington, MA: Lexington Books.

29. Hoang, H., \& B. Antoncic. (2003). Network-based research in entrepreneurship: A critical review. Journal of Business Venturing, 18, 165-187.

30. Huber, G. P. (1991). Organizational learning: The contributing processes and the literatures. Organization Science, 2(1), 88-115.

31. Humphreys, M.A. \& H. McClung. (1991). Women entrepreneurs in Oklahoma. Review of Regional Economics and Business, 6(2), 13-20.

32. Ibarra, H. (1993). Personal networks of women and minorities in management: A conceptual framework. Academy of Management Review, 18(1), 56-87.

33. Kemelgor, B. \& R. D’Souza. (2009). Does expertise matter in an ever changing and uncertain environment? A study of the entrepreneurial process of serial and novice entrepreneurs. Small Business Institute National Proceedings, 33(1), 104-123.

34. Klyver, K. \& S. Terjesen. (2007). Entrepreneurial network composition: An analysis across venture development stage and gender. Women in Management Review, 22(8), 682-688.

35. Lee, R. \& O. Jones (2008). Networks, communication and learning during business start-up - The creation of cognitive social capital. International Small Business Journal, 26(5).

36. Lender, C. (2003) Management, professionals and funding of university business incubators worldwide, paper presented at the 48th ICSB Conference, Belfast, June.

37. Littunen, H. (2000). Networks and local environmental characteristics in the survival of new firms. Small Business Economics, 15, 59-71.

38. Low, M. B., I.C. MacMillan. (1988). Entrepreneurship: Past research and future challenges. Journal of Management, 14: 139-161.

39. March, J. G. (1991). Exploration and exploitation in organizational learning. Organization Science, 2(1), 71-87.

40. McPherson, J. M. \& S. Smith-Lovin. (1986). Sex segregation in voluntary associations. American Sociological Review, 51, 61-79.

41. Miller, N.J., T.L. Besser, \& J.V. Riibe. (2006/2007). Do strategic business networks benefit male- and female-owned small-community businesses? Journal of Small Business Strategy, 17(2) 53-74.

42. Nahapiet, J. \& S. Ghoshal. (1998). Social capital, intellectual capital, and the organizational advantage, Academy of Management Review, 23, 242-266.

43. Nebus, J. (2006). Building collegial information networks: A theory of advice network generation. Academy of Management Review, 31(3), 615-637.

44. Robinson, S. \& Stubberud, H.A. (2009a). Business incubator explanations: Networking and gender differences. Management Review: An International Journal, 4(2), 4-28.

45. Robinson, S. \& Stubberud, H.A. (2009b). Sources of advice in entrepreneurship: Gender differences in business owners' social networks. International Journal of Entrepreneurship, 13, 83-101.

46. Sandberg, K. W. (2003). An exploratory study of women in micro enterprises: Gender-related differences. Journal of Small Business and Enterprise Development, 10(4), 408-417.

47. Schwartz, E.B. (1976). Entrepreneurship: A new female frontier, Journal of Contemporary Business, Winter, 47-76.

48. Shaw, E. (2006). Small firm networking - An insight into contents and motivating factors. International Small Business Journal, 24(1), 5-29. 
49. Silversides, G. (2001), Networking and identity: The role of networking in the public image of professional service firms. Journal of Small Business and Enterprise Development, 8 (2), 174-84.

50. Smeltzer, L. R., \& G. L. Fann. (1989). Gender differences in external networks of small business owner/managers. Journal of Small Business Management, 27 (2), 25-32.

51. Smeltzer, L. R., G. L. Fann, \& V. N. Nikolaisen. (1988). Environmental scanning practices in small business. Journal of Small Business Management, July, 55-62.

52. Smeltzer, L. R., B. L. Van Hook, \& R. W. Hutt. (1991). Analysis of the use of advisors as information sources in venture startups. Journal of Small Business Management, July, 10-20.

53. Taylor, D.W. \& R. Thorpe. (2004). Entrepreneurial learning: A process of co-participation. Journal of Small Business and Enterprise Development, 11(2), 203-211.

54. Teece, D, G. Pisano, \& A. Shuen. (1997). Dynamic capabilities and strategic management." Strategic Management Journal, 18(7), 509-533.

55. Watson, J. (2007). Modeling the relationship between networking and firm performance. Journal of Business Venturing, 22, 852-874.

56. Wu, C., \& A. Young. 2002. Critical operating problems and survival rates in small firms: A look at small business institute clients, Journal of Developmental Entrepreneurship, 7:1-23.

57. Zhao, L. \& J.D. Aram. (1995). Networking and growth of young technology-intensive ventures in China. Journal of Business Venturing, 10, 349-370. 